\title{
Evaluation of factors influencing transmissivity in fractured hard-rock aquifers of the Limpopo Province
}

\author{
Martin Holland* \\ Delta h, PO Box 66662, Woodhill 0076, South Africa
}

\begin{abstract}
Geologically-complex fractured aquifers underlie large parts of the semi-arid Limpopo Province where some of the greatest groundwater needs in South Africa occur. It is important to identify potentially high-yielding zones that can be targeted for water supply. The study covered 7 distinct groundwater regions within Limpopo Province, together covering about 63500 $\mathrm{km}^{2}$. Results from over 4000 pumping-test analyses indicated that geological setting (e.g. aureole of granitoids), proximity and orientation of dykes and lineaments and proximity of surface-water drainages may exert an influence on borehole productivity. Although dykes are poor groundwater targets, drilling dykes composed of dolerite may prove to be more successful. Lineaments striking perpendicular to the current maximum horizontal stress seem to be more favourable targets, which is inconsistent with the predicted regime. Due to the complex geological history, it is difficult to link open discontinuities to a distinct recent or past tectonic event. Regional stress-field data, as in this case, may not account for local, possibly highly significant, stress-field variations. The hydrogeological importance of several factors related to groundwater occurrence, can be used as a working reference for future groundwater-development programmes.
\end{abstract}

Keywords: Limpopo Province, groundwater, transmissivity, lineaments, borehole productivity

\section{Introduction}

The development of hard-rock aquifers as a reliable source of rural water supply is notoriously complicated, and transmissivities are spatially highly variable (Wright, 1992; Chilton and Foster, 1995; Banks and Robins, 2002). Due to the low intrinsic primary permeability and porosity of the hard bedrock, these aquifers differ in important ways from other aquifer types, and demand specific knowledge and techniques if groundwater is to be extracted and managed efficiently. Depending on the hydrogeological and climatic conditions either the magnitude of natural groundwater resources or hydraulic parameters of rocks represent the limits of groundwater development (Krâsny, 1997). Transmissivity data describe the general ability of an aquifer to transmit water and is vital for developing an understanding of the controls on groundwater occurrence. In many instances the magnitude of transmissivity (aquifer permeability) affords a notion about the water-bearing characteristics of hydrogeological bodies and is a decisive factor for groundwater-abstraction possibilities. However, numerous independent or interrelated factors, such as geomorphology (topography), lithology, brittle (neo-) tectonics, and surface-water hydrology, all play a significant role in the occurrence of groundwater in hard-rock environments, because together they control the:

- Nature and depth of the regolith

- Development of fracture and fault zones

- Presence of higher porosity material (or adjacent alluvium)

This paper was originally presented at the International Conference on Groundwater: Our Source of Security in an Uncertain Future, Pretoria, 19-21 September 2011.

* To whom all correspondence should be addressed.

푠 +27 82497 9088; e-mail: martin@delta-h.co.za
The influence of topography on borehole yield has been shown by many (e.g. McFarlane et al., 1992; Henriksen, 1995; Mabee, 1999) with the common result that wells located in valleys and flat areas show generally higher yields compared to wells located on slopes and hilltops. Although specific rock types (e.g. granite, gneiss and schist) are in many cases the obvious factor in explaining the variations in borehole yields (Gustafson and Krásný, 1994; Neves and Morales, 2007), the influence is often supplanted by secondary features such as faults, fracture zones and dykes. Throughout the past decade the optimisation of the location of boreholes (wells) in tectonically fractured areas throughout Africa, India and Brazil has focused mainly on assessing the relationship between bedrock structure and groundwater production by analysing the position of wells in relation to lineaments (e.g. Fernandes and Rudolph, 2001; Solomon and Quiel, 2006; Henriksen and Braathen, 2003; Owen et al., 2007; Ranganai and Ebinger, 2008). Despite the unresolved relationship between lineaments and subsurface permeability (e.g. Greenbaum, 1992; Gustafson and Krásný, 1994), the use of lineament identification in groundwater exploration will continue to be an important initial guide to borehole target selection at the regional level. This is especially true for the Limpopo Province where some of South Africa's greatest groundwater needs occur. Groundwater is the only dependable source of water for many users but is available in varying quantities depending upon the hydrogeological characteristics of the underlying aquifer. Heterogeneous fractured aquifers are distributed throughout the Province and transmissivity may vary by an order of magnitude from one borehole to the next. Knowledge of the variation and distribution of transmissivity provides a basis for future groundwater development and protection. It is important to identify potentially high transmissivity zones that can be targeted for water supply to sustain areas of high population density with few or no alternative water sources. In order to enhance the current understanding of groundwater occurrence in the Limpopo Province the variation 


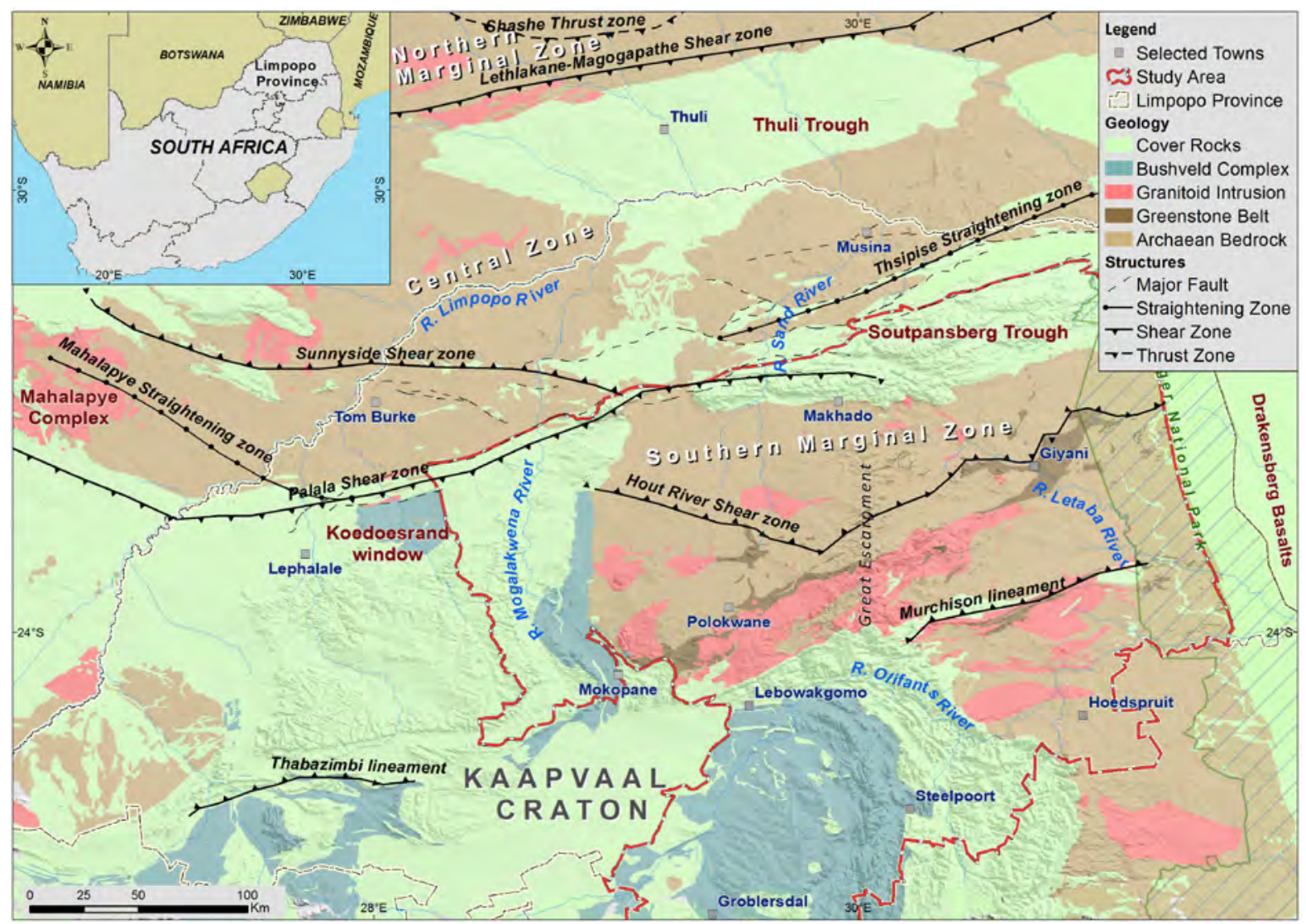

Figure 1

Area of investigation in South Africa (adapted from Boshoff et al., 2006)

of transmissivity is studied in terms of the following factors:

- Hydrogeological and geological setting

- Dykes and linear anomalies (including their orientation) and proximity to rivers.

This paper uses data obtained during the Limpopo Province GRIP (Groundwater Resources Information Project)

Programme, and provides a statistical analysis of the relationship between transmissivity and geological structures. This study builds on the knowledge base set up by Holland and Witthüser (2011) who outlined the relationship of 5 influencing factors on groundwater productivity focusing on the crystalline rocks of the Limpopo Province. These factors included:

- The geological and topographic setting

- Dykes and linear anomalies (including their orientation)

- Regional tectonics (maximum horizontal stress)

- Weathering thickness

- Proximity to surface water drainages.

\section{Study area}

The study covers an area of $63500 \mathrm{~km}^{2}$ in the Limpopo Province and covers part of the junction between the granitegreenstone terrain of the north-eastern part of the Kaapvaal Craton and the highly metamorphic rocks of the Southern Marginal Zone of the Limpopo Mobile Belt (Fig. 1). The study area is drained by 4 major river systems namely the Mogalakwena, Sand, Letaba and Olifants Rivers. The runoff is highly seasonal and variable, with intermittent flow in many of the tributaries. Rainfall varies spatially between $300 \mathrm{~mm}$ and $1000 \mathrm{~mm}$ and orographic rains occur frequently along the escarpment and mountain ranges.

\section{Geological context}

Several major shears (crustal transforms) subdivide the Limpopo Mobile Belt and the Kaapvaal Craton into ENE blocks (domains) of which some have been active from Achaean to recent times. The northern lobe of the Bushveld Complex is truncated by the Palala shear zone in the north, and separated from the western and eastern lobes in the south by the Murchison/Thabazimbi lineament. The northward dipping Hout River Shear Zone forms the boundary between the lowgrade granitoid-greenstone terrain of the Kaapvaal Craton to the south and the higher grade rocks of the Southern Marginal Zone to the north. Its counterpart, the Northern Marginal Zone, separates the Zimbabwe Craton from the Northern Marginal Zone (Fig. 1).

Geologically the study area is almost entirely underlain by crystalline lithologies, which include; Achaean age basement complexes (gneiss, greenstones, etc.); the northern and eastern limb of the Bushveld igneous complex; the Soutpansberg lavas; the Transvaal Group (quartzites); and the Chuniespoort Group dolomites. The central parts of the study area are dominated by the Palaeoachaean (3 600 to 3200 million years) gneissic bodies bordered to the north by the Soutpansberg Mountains (volcanic rocks), to the west by the Northern limb of the Bushveld Complex (2,050 million years) and to the east by the Drakensberg basalts of the Lebombo Mountains. Achaean greenstone belts are infolded mainly into grey granitic 


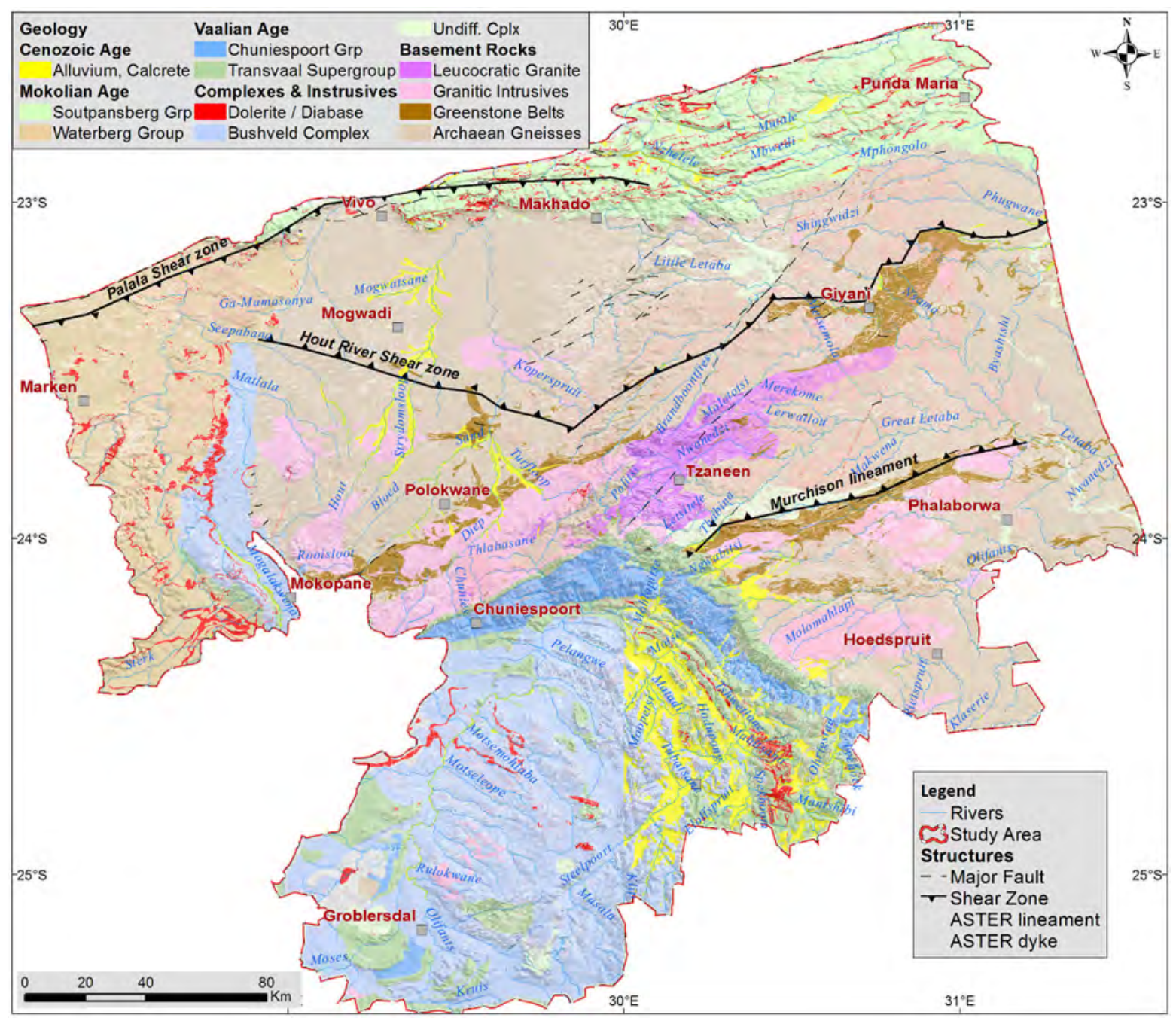

Figure 2

Regional geology of the study area

gneisses which dominate the early Achaean terrains (Brandl et al., 2006). A number of massive, unfoliated granite intrusions occur as batholiths, plutons and stocks in the study area (2 800 to 2500 million years). These granitic intrusions form prominent topographic features that can be seen north of Polokwane. The Duiwelskloof leucogranites, which form an elongated northeast-trending batholith, are the most voluminous granite bodies in the study area (Fig. 2). To the south the area is dominated by the eastern lobe of the Bushveld Complex, which is intrusive into Transvaal Super Group strata. The Transvaal Group strata run parallel to the dip and strike of the outer rim of the Bushveld Complex. The Waterberg Group sandstones cover most of the quadrant in the western parts of the study area.

One of the most differentiating structural features of the study area is the frequency and orientation of dyke swarms. Dyke swarms may be useful palaeo-stress indicators as the trend of the intruded dykes is determined by the principal stress direction operative at the time of intrusion (Stettler et al., 1989). The age and orientation of the predominantly ENE to NE trending dyke swarms and associated aeromagnetic lineaments coincide with the 2700 million years Ventersdorp rift structures, but also include similar NE trending Karoo-age dolerite dykes (Uken and Watkeys, 1997). During this period the north-eastern Kaapvaal Craton underwent NW-SE extension, in contrast to the current NE-SW extensional regime (Bird et al., 2006). On the basis of data incorporated into the World Stress Map database there is a suggestion of a horizontal principal stress direction oriented NW to NNW (Heidbach et al., 2008).

\section{Hydrogeological context}

The predominant aquifers in the study area are structurally controlled weathered and fractured aquifers. In areas where a thinner weathered regolith is present, the focus is predominantly on the dominant fissure/fracture flow developed in the underlying fractured bedrock. The valley floors are generally covered by a variable thickness of alluvium that overlie or replace the regolith and create a distinct intergranular aquifer type. To determine how groundwater conditions vary over this extensive study area, it was deemed necessary to divide the area based on Vegter's (2000) groundwater regions (Fig. 3). These groundwater regions are primarily based on rock type, geological age and lithostratigraphy, while some consideration was given to physiography and climate. A summary of the geological characteristics of the 7 groundwater regions found in the study area is provided in Table 1. 


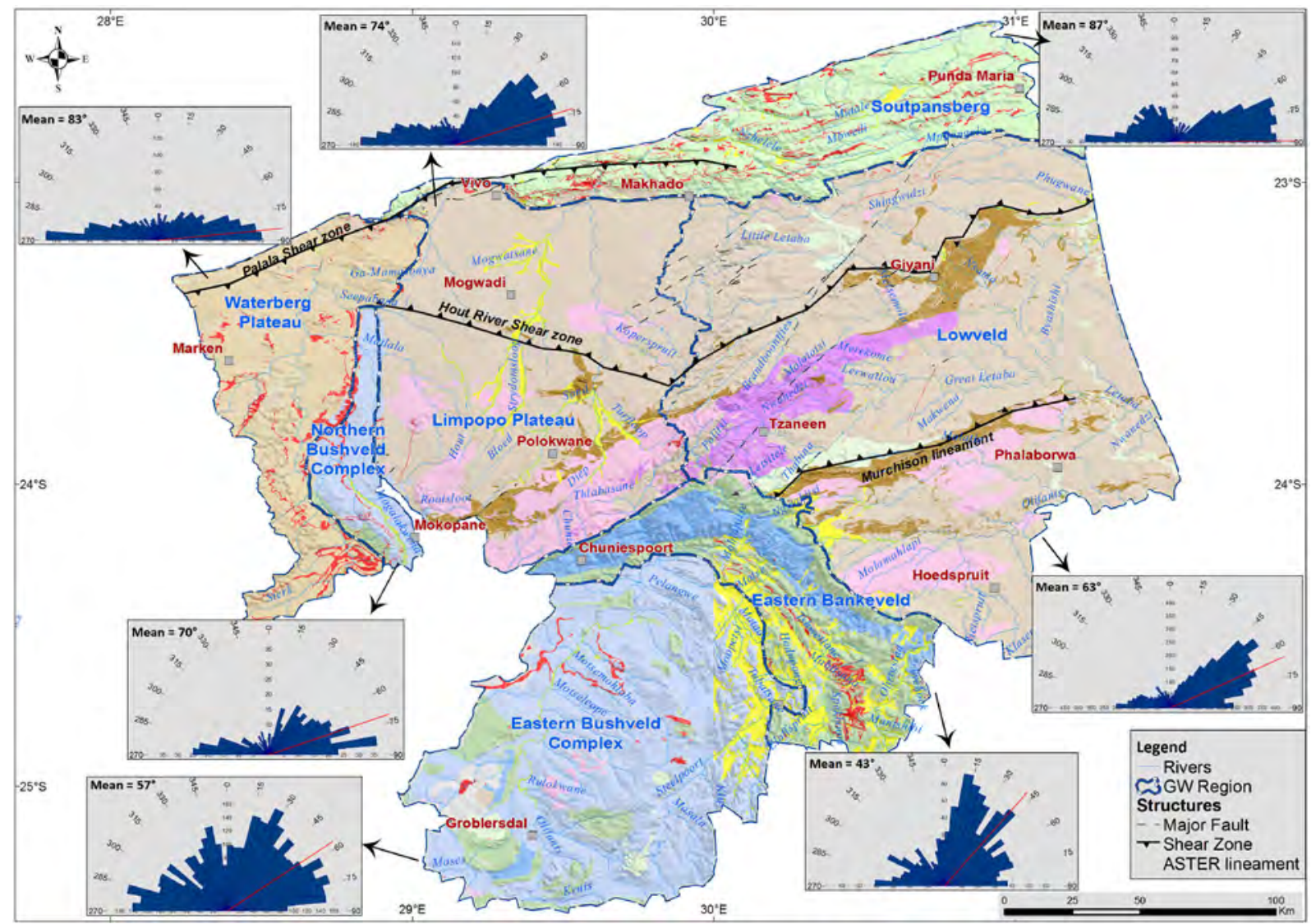

Figure 3

Groundwater regions with lineament frequency rose diagram showing main structural trends

\begin{tabular}{|l|l|l|}
\hline \multicolumn{3}{|c|}{ Characteristics of identified groundwater regions in the study area (adapted from Vegter, 2000) } \\
\hline Region Name & Main water-bearing rock & Main lineament trend \\
\hline Eastern Bankeveld & Pretoria Group shale and quartzite; Chuniespoort dolomite & $10^{\circ}$ to $45^{\circ}$ (NNE to NE) \\
\hline $\begin{array}{l}\text { Eastern Bushveld } \\
\text { Complex }\end{array}$ & $\begin{array}{l}\text { Rustenburg layered suite (mafic rocks); Lebowa suite; other } \\
\text { gneisses, migmatites and volcanic rocks }\end{array}$ & $\begin{array}{l}20^{\circ} \text { to } 80^{\circ} \text { (NNE to ENE), 270 } \\
\text { (W to } 300^{\circ}\end{array}$ \\
\hline Lowveld & $\begin{array}{l}\text { Hout-River Gouplaats Gneiss; Letaba Gneiss; greenstones; } \\
\text { igneous intrusive rocks and other complexes }\end{array}$ & $40^{\circ}$ to $75^{\circ}$ (NE) \\
\hline $\begin{array}{l}\text { Northern Bushveld } \\
\text { Complex }\end{array}$ & Rustenburg layered suite (mafic rocks); Lebowa suite & $30^{\circ}$ to $80^{\circ}$ (NE to ENE) \\
\hline Limpopo Plateau & $\begin{array}{l}\text { Hout-River Gouplaats Gneiss; Bandelierkop complex; green- } \\
\text { stones; igneous intrusive rocks }\end{array}$ & $40^{\circ}$ to $80^{\circ}$ (NE to ENE), 270 ${ }^{\circ}$ to $290^{\circ}$ (W) \\
\hline Soutpansberg & Soutpansberg Group sandstone, shale, basalt (lavas) and tuff & $\begin{array}{l}60^{\circ} \text { to } 90^{\circ} \text { (ENE to E), } 270^{\circ} \text { to } 330^{\circ} \\
\text { (W to } \mathrm{WNW}^{\circ}\end{array}$ \\
\hline Waterberg Plateau & $\begin{array}{l}\text { Waterberg Group sandstone, shale conglomerate, mudstone } \\
\text { and siltstone }\end{array}$ & $70^{\circ}$ to $90^{\circ}$ (E), 270 to $290^{\circ}$ (W) \\
\hline
\end{tabular}

\section{Method of analysis}

The borehole dataset compiled for the study consisted of over 17000 boreholes contained in the Groundwater Resources Information Project (GRIP) Limpopo database of the South African Department of Water Affairs. As the majority of these boreholes have been verified in the field, the spatial accuracy of borehole positions is within $10 \mathrm{~m}$. Approximately 4000 boreholes have been hydraulically tested and the geology has been logged on 1200 of these boreholes. Borehole logs are captured as part of the GRIP project but the analysis of the logs was done as part of this investigation. The majority of the pumping tests were single-well tests, primarily to recommend sustainable abstraction rates for rural water-supply schemes. It is important to note that these boreholes are not randomly distributed but were limited to the proximity of rural villages. In some cases the drilling target was chosen based on either geophysical field surveys or geological expertise, so a bias towards lineaments and other anomalies in the dataset are apparent. Similarly, the pumping test results are biased towards larger transmissivity and yield values since low yielding or dry boreholes were excluded from testing. Although the 
determination of aquifer parameters was not a priority in the GRIP framework, pumping tests of more than 2000 boreholes within the study area were analysed using classical analytical models such as Theis (1935) and the Jacob's approximation (Cooper and Jacob, 1946) method. These methods, in addition to analytical methods such as Logan (1964), are collated, together with graphical plots (e.g. semi-log, log-log and derivatives), into the flow characteristic (FC) Excel spreadsheet developed by the Institute for Groundwater Studies in South Africa (Van Tonder et al., 2001). As a result, despite the fact that various consultants and contractors were used to conduct and analyse the pumping tests over a number of years within the GRIP project framework, all analyses were conducted using the FC-spreadsheet. Transmissivity estimates are mainly based on a late time fit of the time-drawdown curve using, for example, Cooper-Jacob or Theis methods, or by estimating the effective transmissivity values from the average maximum derivatives (representing $T$-late). It should be noted that the pumping test data have been accumulated over a number of years under various conditions and may potentially be influenced by long-term climatic fluctuations, seasonal rainfall and changes in groundwater abstraction by farmers, communities and mines.

\section{Spatial analysis}

Analysis of large datasets in regional studies requires the application of geographical information systems (GIS). The visual representation of the associated geographic phenomena together with their spatial dimensions and their associated attributes provides a rapid, integrated and cost-effective tool in any groundwater investigation. The approach used in this study was based on a traditional one to assess the relationship between the transmissivity to geology, proximity of surfacewater drainages, and proximity and orientation of linear geological features (e.g. inferred dykes and interpreted lineaments). A hydrogeological database was created in ArcGIS using the 1:250 000 geological and 1:50 000 topographic vector files as well as borehole coordinates including hydrogeological attributes. With this approach it was possible to extract spatial information based on the location of a borehole (e.g. geology, proximity to a lineament, dyke or river course, etc.). The geological logs were used to indicate whether diabase or dolerite was encountered during drilling, representing the intersection of a dyke. Boreholes were then grouped according to their location or lithological setting and the corresponding arithmetic mean and in some cases geometric mean values of transmissivity.

\section{Lineament analysis}

The use of lineament mapping, especially in crystalline lithologies with poor primary porosity, is of major importance for groundwater exploration and was incorporated into the GRIP framework by the Department of Water Affairs (DWA) for the Limpopo Province. The mapping and interpretation of lineaments is conducted by geological remote-sensing consultants on behalf the DWA Limpopo Regional Office. The satellite imagery used for the capturing of lineaments is from the medium resolution ASTER (Advanced Spaceborne Thermal Emission and Reflectance) missions. ASTER data are a good choice for groundwater development projects, due to their large spectral resolution, reasonably high spatial resolution, ability to derive DEMs (digital elevation models) and low cost of acquiring the imagery (Sander, 2007). The mapping of lineaments in the Limpopo Province takes place in a digital environment using GIS and is mapped at a scale of 1:50 000 (Anke, 2008). The step-by-step extraction and processing of the linear features are not described in detail but the resulting features are classified, where possible, as dykes, faults (very limited) and lineaments. The dataset consists of over 17000 linear features over the study area. These interpreted lineaments may reflect a number of features such as faults, fracture zones, joints, foliations, dykes, lithological contacts and linear branches of the drainage systems. It is recognised that lineament mapping is often subjective (Wise, 1982; Mabee et al., 1994) and that a 2-dimensional lineament of geological origin, mapped on remote-sensing imagery, provides little direct information on the type of feature, its depth, dip or potential infilling (Sander, 2007). As a result, certain assumptions had to be made in order to determine the extent to which these lineaments influence or relate to borehole productivity in the Limpopo Province on a regional scale. According to Braathen and Gabrielsen (1998) a large lineament can enhance fracturing up to $300 \mathrm{~m}$ away while Clark (1985) suggested that the area of influence might be less than $150 \mathrm{~m}$ and Fernandes and Rudolph (2001) reduced it further to $70 \mathrm{~m}$ in their studies. Considering the spatial margin, all boreholes within $150 \mathrm{~m}$ of a lineament were considered to be targeting a lineament in this study.

\section{Results and discussion}

\section{Groundwater characteristics}

The deepest water levels encountered in the Eastern Bankeveld and Limpopo Plateau region (Table 2). The Soutpansberg region has the shallowest water level with an average of 12.5

\begin{tabular}{|c|c|c|c|c|c|c|c|c|}
\hline \multicolumn{9}{|c|}{$\begin{array}{c}\text { Table } 2 \\
\begin{array}{c}\text { Summary of groundwater characteristics in the study area (in metres below ground } \\
\text { level) (highlighted: dark grey = highest; light gray = lowest) }\end{array}\end{array}$} \\
\hline \multirow[t]{2}{*}{ Groundwater region } & \multicolumn{2}{|c|}{ BH depth } & \multicolumn{2}{|c|}{ Water level } & \multicolumn{2}{|c|}{ Water strike } & \multicolumn{2}{|c|}{$\begin{array}{l}\text { Weathering } \\
\text { depth }\end{array}$} \\
\hline & $N$ & Mean & $N$ & Mean & $N$ & Mean & $N$ & Mean \\
\hline Eastern Bankeveld & 448 & 67 & 372 & 18.0 & 105 & 35.3 & 106 & 22.1 \\
\hline Eastern Bushveld Complex & 1847 & 68 & 1434 & 13.2 & 307 & 33.2 & 386 & 17.3 \\
\hline Lowveld & 3470 & 65 & 2610 & 14.7 & 849 & 31.5 & 815 & 18.0 \\
\hline Northern Bushveld Complex & 397 & 64 & 293 & 13.9 & 46 & 26.0 & 56 & 16.3 \\
\hline Limpopo Plateau & 2227 & 68 & 1634 & 17.6 & 419 & 37.2 & 448 & 22.1 \\
\hline Soutpansberg & 782 & 69 & 682 & 12.5 & 159 & 37.6 & 147 & 16.9 \\
\hline Waterberg Plateau & 768 & 72 & 546 & 14.2 & 110 & 34.7 & 130 & 17.4 \\
\hline Total & 9939 & 67 & 7571 & 15.0 & 1995 & 33.7 & 2088 & 18.8 \\
\hline
\end{tabular}

http://dx.doi.org/10.4314/wsa.v38i3.3

Available on website http://www.wrc.org.za

ISSN 0378-4738 (Print) = Water SA Vol. 38 No. 3 International Conference on Groundwater Special Edition 2012

ISSN 1816-7950 (On-line) = Water SA Vol. 38 No. 3 International Conference on Groundwater Special Edition 2012 


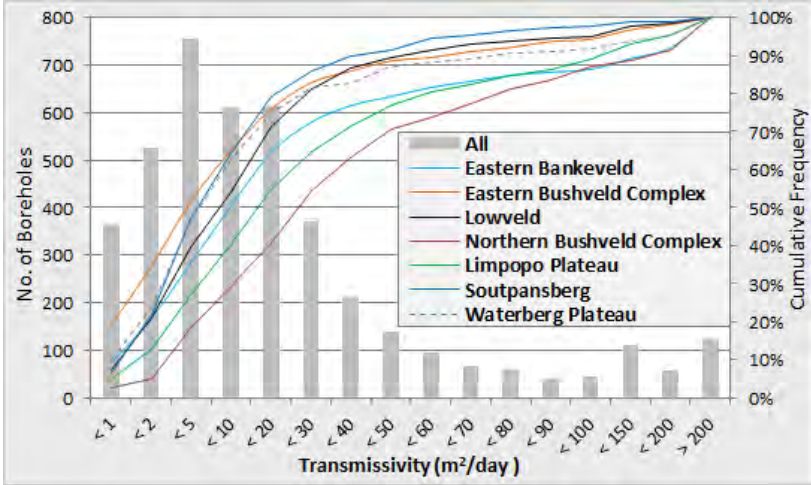

Figure 4

Frequency histograms and cumulative distribution of transmissivities $\left(\mathrm{m}^{2} / \mathrm{d}\right)$

metres below ground level ( $\mathrm{m}$ bgl). Generally boreholes drilled in the Waterberg region extend to below $70 \mathrm{~m}$ bgl, while boreholes drilled in the Northern Bushveld Complex region have the shallowest drilling depth with an average of $63 \mathrm{~m}$ bgl. The average depth of water strikes over the study area is $33.7 \mathrm{~m} \mathrm{bgl}$ which exceeds the average weathering depth (generally less than $20 \mathrm{~m}$ ) suggesting that productive yields are mainly derived from water-bearing fractures struck at depth. Deeper weathering depths are generally characterised by deeper water strikes and water levels.

\section{Distribution of data}

The positively skewed distributions of transmissivity values for the 7 groundwater regions are shown in Fig. 4. Log-normal distributions are frequently reported in regional studies of fractured-rock aquifers (e.g. Hoeksema and Kitanidis, 1985; Razack and Lasm, 2006). For multivariate statistics the data should be log-transformed but in this study the distinctions between the groups shaped the basic method for the research and no values were log-transformed.

Seventy percent of derived transmissivities lie below $20 \mathrm{~m}^{2} / \mathrm{d}$; however, several significantly higher transmissivities (outliers), especially in the Eastern Bankeveld, Limpopo Plateau, and the Northern Bushveld Complex 'push' the mean for the larger area to $33 \mathrm{~m}^{2} / \mathrm{d}$ (Table 3). These mentioned groundwater regions appear to offer greater groundwater potential compared to the Soutpansberg and the Eastern Bushveld Complex (Fig. 4). When averaging transmissivity (and hydraulic conductivity) the geometric mean is often used for describing the heterogeneous media (de Marsily et al., 2005). This reduces bias associated with occasional exceptionally high values (> than $20 \mathrm{~m}^{2} / \mathrm{d}$ ). The log-normally distributed transmissivity data would suggest that the average would lie between the harmonic and arithmetic means and are better described by the geometric mean. Although the harmonic mean is proposed by some (e.g. Pinales et al., 2005) to represent average permeability, the variation between regions is minimal (Table 3) and therefore it was not considered in further analyses.

\section{Geological setting}

Boreholes were grouped according to the position of the borehole with respect to mapped lithological units. Further boreholes within a $100 \mathrm{~m}$ buffer zone along major river courses were regarded as representing potential alluvial aquifers (or drainage areas). Similarly a $500 \mathrm{~m}$ buffer (in- and outside of the mapped features) was used to present the metamorphic aureole that developed during the granite intrusion of the batholiths outcropping mostly in the Limpopo Plateau. The corresponding mean values were calculated and compared to the total population (Table 4).

The results show that measured transmissivity values vary spatially throughout the study area and a distinct variability exists between the geological settings. Values of transmissivity span an order of magnitude, and the wide range can be attributed to tectonic fracturing and heterogeneity of aquifers. The highest transmissivity is - as expected - observed in the karstic Chuniespoort Dolomite Aquifer, whilst the least productive boreholes are observed in boreholes targeting the granitic batholiths (intrusives). Similarly low productivities are associated with the elongated leucogranites straddling the escarpment between the Limpopo Plateau and Lowveld with average transmissivities of $7 \mathrm{~m}^{2} / \mathrm{d}$. However, boreholes located along the contact zones of these batholiths provide evidently higher potential for groundwater development. These granitic intrusives can displace the host rocks during intrusion in order to create space for the ascending magma. A number of physical changes occur in the host rock, e.g. tension jointing, peripheral cleavage and ductile deformation, enhancing the water-bearing characteristics of the host rock (Du Toit, 2001). The Lowveld gneisses which lie to the west of the escarpment have a much lower productivity compared to the Limpopo Gneiss (Plateau). The Limpopo (Plateau) Achaean gneisses pose a number of exceptionally high-yielding areas not known anywhere else in Africa, within the crystalline basement aquifer system. These zones are highly productive which may be related to factors such as fracture density and susceptibility to weathering and can yield boreholes producing in excess of $40 \mathrm{l} / \mathrm{s}$ with transmissivity exceeding $500 \mathrm{~m}^{2} / \mathrm{d}$. Due to the inherently higher

\begin{tabular}{|c|c|c|c|c|c|}
\hline \multicolumn{6}{|c|}{$\begin{array}{c}\text { Table } 3 \\
\begin{array}{c}\text { Statistical summary of transmissivities of the } 7 \text { groundwater regions } \\
\text { (highlighted: dark grey = highest; light gray = lowest) }\end{array}\end{array}$} \\
\hline Groundwater region & $N$ & Mean & $\begin{array}{c}\text { Std. } \\
\text { deviation }\end{array}$ & $\begin{array}{c}\text { Geometric } \\
\text { mean }\end{array}$ & $\begin{array}{c}\text { Harmonic } \\
\text { mean }\end{array}$ \\
\hline Eastern Bankeveld & 240 & 63.32 & 203.8 & 12.33 & 4.07 \\
\hline Eastern Bushveld Complex & 573 & 28.27 & 79.9 & 7.09 & 2.94 \\
\hline Lowveld & 1650 & 25.19 & 83.8 & 8.37 & 3.62 \\
\hline Northern Bushveld Complex & 173 & 54.83 & 75.8 & 23.46 & 9.13 \\
\hline Limpopo Plateau & 709 & 45.16 & 84.6 & 15.40 & 5.43 \\
\hline Soutpansberg & 402 & 17.98 & 42.4 & 6.59 & 3.28 \\
\hline Waterberg Plateau & 249 & 38.20 & 105.3 & 8.21 & 3.48 \\
\hline Total & 3996 & 32.83 & 94.1 & 9.50 & 3.80 \\
\hline
\end{tabular}




\begin{tabular}{|c|c|c|c|c|c|c|c|}
\hline \multicolumn{8}{|c|}{$\begin{array}{c}\text { Table } 4 \\
\begin{array}{c}\text { Determined hydrogeological parameters based on the lithological setting of } \\
\text { boreholes (highlighted: dark grey = highest; light gray = lowest) }\end{array}\end{array}$} \\
\hline \multirow[t]{3}{*}{ Geological setting } & \multicolumn{7}{|c|}{ Transmissivity $\mathrm{m}^{2} / \mathrm{d}$} \\
\hline & \multirow[t]{2}{*}{$N$} & \multirow[t]{2}{*}{ Mean } & \multirow{2}{*}{$\begin{array}{l}\text { Geo- } \\
\text { mean }\end{array}$} & \multirow{2}{*}{$\begin{array}{c}\text { Std } \\
\text { error }\end{array}$} & \multicolumn{3}{|c|}{$90 \%$ Confidence Interval } \\
\hline & & & & & Lower & Upper & $\begin{array}{c}\text { Final } \\
\text { Rank* }^{*}\end{array}$ \\
\hline Alluvium & 463 & 55.7 & 14.9 & 1.1 & 13.2 & 16.8 & 3 \\
\hline Achaean Gneisses (Limpopo) & 452 & 53.0 & 17.3 & 1.4 & 15.2 & 19.6 & 4 \\
\hline Achaean Gneisses (Lowveld) & 1017 & 21.0 & 7.5 & 0.4 & 6.9 & 8.1 & 10 \\
\hline Chuniespoort Group & 37 & 120.2 & 19.3 & 6.8 & 11.3 & 33.1 & 1 \\
\hline Dolerite / diabase & 60 & 29.1 & 8.0 & 1.6 & 5.9 & 10.9 & 7 \\
\hline Eastern Bushveld Complex & 603 & 25.2 & 4.7 & 0.3 & 4.2 & 5.3 & 13 \\
\hline Granitic Intrusives & 113 & 6.5 & 2.8 & 0.3 & 2.3 & 3.5 & 14 \\
\hline Greenstone Belts & 186 & 27.7 & 10.5 & 1.2 & 8.7 & 12.7 & 6 \\
\hline Intrusive Contact & 171 & 26.0 & 7.7 & 1.0 & 6.2 & 9.6 & 8 \\
\hline Leucocratic Granite & 180 & 7.3 & 3.1 & 0.3 & 2.6 & 3.6 & 15 \\
\hline Northern Bushveld Complex & 153 & 56.3 & 23.2 & 3.0 & 18.8 & 28.6 & 2 \\
\hline Soutpansberg Group & 339 & 15.6 & 5.8 & 0.4 & 5.2 & 6.6 & 11 \\
\hline Transvaal Supergroup & 133 & 37.6 & 6.7 & 1.0 & 5.3 & 8.5 & 9 \\
\hline Undifferentiated complex & 83 & 29.7 & 12.7 & 2.0 & 9.7 & 16.3 & 5 \\
\hline Waterberg Group & 194 & 29.3 & 5.3 & 0.6 & 4.4 & 6.5 & 12 \\
\hline Total & 4184 & 31.4 & 8.1 & 0.2 & 7.7 & 8.4 & - \\
\hline
\end{tabular}

* Ranking based on the geometric mean and standard error while considering specific knowledge

Figure 5

Spatial distribution of transmissivity values obtained from pumping-test analysis

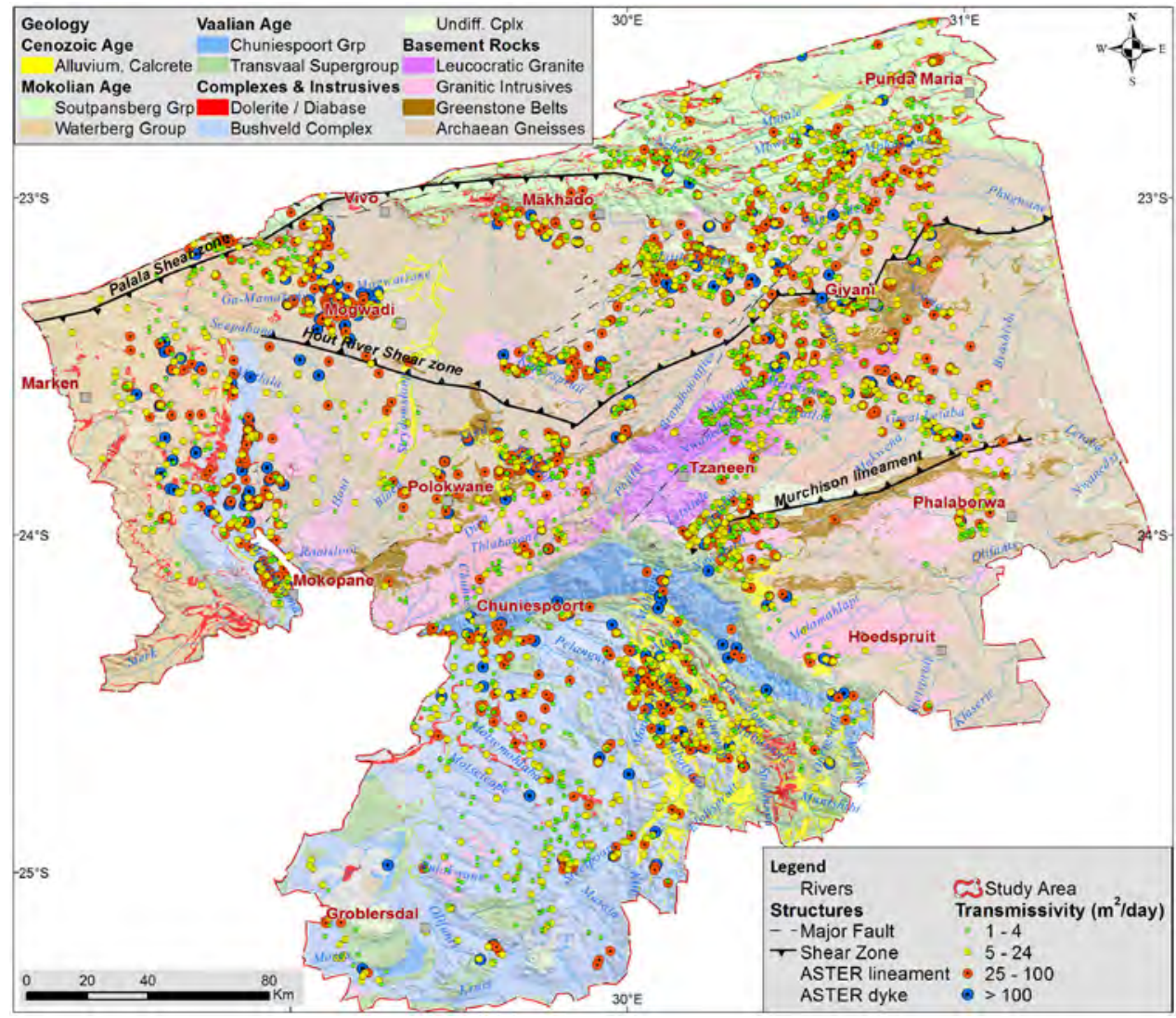

primary porosity of the alluvial aquifers compared to the Achaean gneisses it was awarded a higher ranking in terms of groundwater development. The second most productive geological setting is the Northern Bushveld Complex with a geometric mean of $23 \mathrm{~m}^{2} / \mathrm{d}$. The various layered lithologies of the Bushveld Complex deform similarly in a brittle environment and the potential to host groundwater will depend on the susceptibility to weathering of the rocks. Based on the information provided in Table 2 the Northern Bushveld Complex is also characterised by the shallowest water strike and below-average water levels suggesting a shallow highly productive composite weathered and fractured aquifer system. This is also confirmed by a visual inspection of the spatial transmissivity distribution map (Fig. 5). 


\begin{tabular}{|c|c|c|c|c|}
\hline \multicolumn{5}{|c|}{$\begin{array}{c}\text { Table } 5 \\
\text { Transmissivity }\left(T, \mathrm{~m}^{2} / \mathrm{d}\right) \text { according to boreholes } \\
\text { intercepting dykes (highlighted: dark grey = highest; light } \\
\text { gray = lowest) }\end{array}$} \\
\hline & Dyke logged & Diabase & Dolerite & No dyke \\
\hline \multirow{3}{*}{ Eastern Bankeveld } & $\mathrm{N}$ & 14 & 3 & 35 \\
\hline & Mean & 15.6 & 12 & 87.9 \\
\hline & Geo-Mean & 3.5 & 7.1 & 8.3 \\
\hline \multirow{3}{*}{$\begin{array}{l}\text { Eastern Bushveld } \\
\text { Complex }\end{array}$} & $\mathrm{N}$ & 18 & $2^{*}$ & 88 \\
\hline & Mean & 2.3 & 37.7 & 18.7 \\
\hline & Geo-Mean & 1.3 & 17.5 & 4.3 \\
\hline \multirow{3}{*}{ Lowveld } & $\mathrm{N}$ & 140 & 28 & 165 \\
\hline & Mean & 14.5 & 23.6 & 25 \\
\hline & Geo-Mean & 3.2 & 12.2 & 7.6 \\
\hline \multirow{3}{*}{$\begin{array}{l}\text { Northern Bushveld } \\
\text { Complex }\end{array}$} & $\mathrm{N}$ & $4^{*}$ & $1^{*}$ & 13 \\
\hline & Mean & 57.5 & 44 & 59.5 \\
\hline & Geo-Mean & 23.4 & 44 & 14.2 \\
\hline \multirow{3}{*}{ Limpopo Plateau } & $\mathrm{N}$ & 56 & 11 & 69 \\
\hline & Mean & 13.4 & 83.1 & 40.8 \\
\hline & Geo-Mean & 4.3 & 47.3 & 10.8 \\
\hline \multirow{3}{*}{ Soutpansberg } & $\mathrm{N}$ & 17 & $1^{*}$ & 48 \\
\hline & Mean & 25.1 & 14 & 11.3 \\
\hline & Geo-Mean & 7.3 & 14 & 4.9 \\
\hline \multirow{3}{*}{ Waterberg Plateau } & $\mathrm{N}$ & 18 & $6^{*}$ & 14 \\
\hline & Mean & 10.8 & 8.1 & 8.3 \\
\hline & Geo-Mean & 4 & 5.9 & 4.2 \\
\hline \multirow{3}{*}{ Total } & $\mathrm{N}$ & 267 & 52 & 432 \\
\hline & Mean & 14.5 & 34.4 & 30.3 \\
\hline & Geo-Mean & 3.6 & 15.1 & 5.7 \\
\hline
\end{tabular}

\begin{tabular}{|c|c|c|c|c|}
\hline \multicolumn{5}{|c|}{$\begin{array}{c}\text { Table } 6 \\
\text { Transmissivity }\left(T, \mathrm{~m}^{2} / \mathrm{d}\right) \text { according to distance to inferred } \\
\text { dykes (highlighted: dark grey = highest) }\end{array}$} \\
\hline & \begin{tabular}{|l} 
Distance to \\
inferred dyke
\end{tabular} & $<50 \mathrm{~m}$ & $\begin{array}{c}50-150 \\
\mathrm{~m}\end{array}$ & $>150 \mathrm{~m}$ \\
\hline \multirow{3}{*}{ Eastern Bankeveld } & $N$ & 8 & 11 & 231 \\
\hline & \begin{tabular}{|l|} 
Mean \\
\end{tabular} & 55.4 & 62.1 & 60.9 \\
\hline & Geo-Mean & 7.7 & 9.1 & 10.6 \\
\hline \multirow{3}{*}{$\begin{array}{l}\text { Eastern Bushveld } \\
\text { Complex }\end{array}$} & $N$ & 17 & 29 & 599 \\
\hline & Mean & 13.1 & 4.7 & 26.5 \\
\hline & Geo-Mean & 3.1 & 1.8 & 5.2 \\
\hline \multirow{3}{*}{ Lowveld } & $N$ & 228 & 372 & 1110 \\
\hline & Mean & 20.6 & 18.9 & 26.9 \\
\hline & Geo-Mean & 5.8 & 5.6 & 8.5 \\
\hline \multirow{3}{*}{$\begin{array}{l}\text { Northern Bushveld } \\
\text { Complex }\end{array}$} & $N$ & 2 & 4 & 170 \\
\hline & Mean & 10.2 & 27.9 & 55.0 \\
\hline & Geo-Mean & 8.7 & 10.4 & 22.1 \\
\hline \multirow{3}{*}{ Limpopo Plateau } & $N$ & 30 & 52 & 645 \\
\hline & \begin{tabular}{|l|} 
Mean \\
\end{tabular} & 45.7 & 53.0 & 43.2 \\
\hline & Geo-Mean & 12.7 & 16.6 & 13.7 \\
\hline \multirow{3}{*}{ Soutpansberg } & $N$ & 4 & 9 & 400 \\
\hline & Mean & 6.4 & 13.8 & 17.7 \\
\hline & Geo-Mean & 3.6 & 5.5 & 6.1 \\
\hline \multirow{3}{*}{ Waterberg Plateau } & $N$ & 19 & 36 & 208 \\
\hline & Mean & 6.8 & 29.2 & 39.9 \\
\hline & Geo-Mean & 3.6 & 5.5 & 7.3 \\
\hline \multirow{3}{*}{ Total } & $N$ & 308 & 513 & 3363 \\
\hline & Mean & 22.4 & 23.2 & 33.4 \\
\hline & Geo-Mean & 5.9 & 5.9 & 8.7 \\
\hline
\end{tabular}

* Low number of boreholes

\section{Relationship to dykes}

As dykes occur extensively in the study area, it is important to establish their role in the occurrence of groundwater. Based on the geological logs, boreholes which encounter diabase dykes have generally lower productivity than boreholes which encounter dolerite dykes. Based on the results, boreholes that intercept dykes have a higher transmissivity compared to boreholes without dyke material (Table 5).

However, based on the proximity of the borehole to inferred dykes (lineament mapped and aeromagnetic) (Fig. 6) no significant relationship between transmissivity and distance to dykes exists. Bush (1989) found similar results and noted that diabase and dyke contact zones had lower yields than boreholes drilled away from dykes. However, it is evident that the influence of dykes on transmissivity in the Limpopo Plateau region is higher compared to other regions (Table 6). Due to the generally high transmissivity of the host rocks (Table 4), the crosscutting of less permeable dykes may act as flow barriers and, in conjunction with the greater fissuring commonly associated with dykes, may enhance the accumulation of water. In areas with a higher dyke density such as the Lowveld region it can be argued the permeability of these closely spaced dykes is not very different from the host rocks, the gneisses or granites, in which they occur.

The observed results would suggest that the influence of dykes on the borehole productivity is more localised and more complex, as high transmissivities are observed in most areas where dykes are encountered during drilling (Table 5);

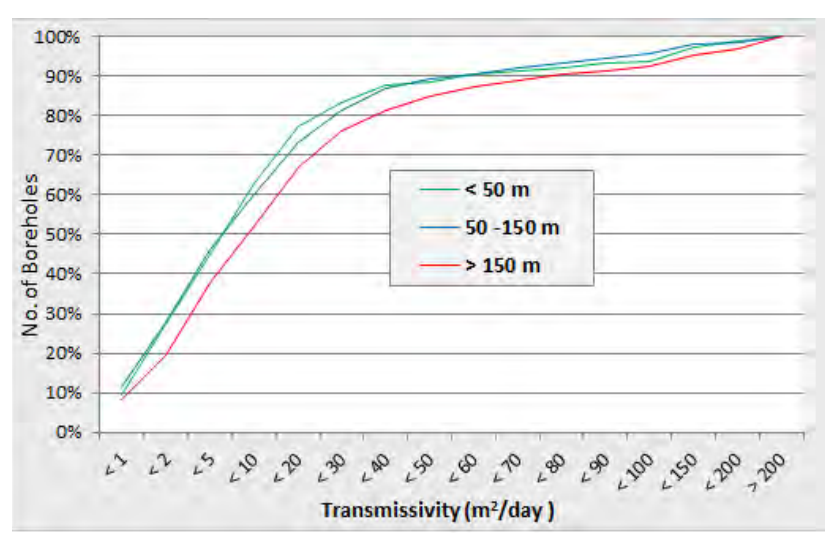

Figure 6

Cumulative frequency distributions showing the influence of the proximity to dykes on transmissivity

however, on a regional scale the regional mapped dykes do not offer better borehole productivities (Table 6). It must be noted that the dataset is biased towards the larger population of boreholes located further than $50 \mathrm{~m}$ and $150 \mathrm{~m}$ from a dyke. In this subgroup numerous other factors may enhance the productivity of a borehole. When assessing the influence of a dyke on the groundwater potential one should also consider their thickness. Pumping tests in Botswana revealed that dolerite dykes thicker than $10 \mathrm{~m}$ serve as groundwater barriers, whereas those that are narrower tend to be permeable due to the fact that cooling joints and fractures are developed in them (Bromley et al., 1994). 


\begin{tabular}{|c|c|c|c|}
\hline \multicolumn{4}{|c|}{$\begin{array}{c}\text { Table } 7 \\
\text { Transmissivity }\left(T, \mathrm{~m}^{2} / \mathrm{d}\right) \text { according to distance to inferred } \\
\text { lineaments (highlighted: dark grey = highest) }\end{array}$} \\
\hline & $\begin{array}{l}\text { Distance to } \\
\text { lineament }\end{array}$ & $150 \mathrm{~m}$ & $>150 \mathrm{~m}$ \\
\hline \multirow{3}{*}{ Eastern Bankeveld } & $N$ & 33 & 217 \\
\hline & Mean & 140.6 & 48.6 \\
\hline & Geo-Mean & 7.4 & 11.2 \\
\hline \multirow{3}{*}{$\begin{array}{l}\text { Eastern Bushveld } \\
\text { Complex }\end{array}$} & $N$ & 108 & 537 \\
\hline & Mean & 44.3 & 21.3 \\
\hline & Geo-Mean & 5.9 & 4.7 \\
\hline \multirow{3}{*}{ Lowveld } & $N$ & 238 & 1472 \\
\hline & Mean & 31.3 & 23.2 \\
\hline & Geo-Mean & 7.9 & 7.3 \\
\hline \multirow{3}{*}{$\begin{array}{l}\text { Northern Bushveld } \\
\text { Complex }\end{array}$} & $N$ & 32 & 144 \\
\hline & Mean & 50.1 & 54.7 \\
\hline & Geo-Mean & 21.6 & 21.5 \\
\hline \multirow{3}{*}{ Limpopo Plateau } & $N$ & 57 & 670 \\
\hline & Mean & 52.0 & 43.4 \\
\hline & Geo-Mean & 20.4 & 13.4 \\
\hline \multirow{3}{*}{ Soutpansberg } & $N$ & 71 & 342 \\
\hline & Mean & 20.5 & 16.9 \\
\hline & Geo-Mean & 6.9 & 5.9 \\
\hline \multirow{3}{*}{ Waterberg Plateau } & $N$ & 38 & 225 \\
\hline & Mean & 27.9 & 37.5 \\
\hline & Geo-Mean & 3.2 & 7.6 \\
\hline \multirow{3}{*}{ Total } & $N$ & 577 & 3607 \\
\hline & Mean & 41.5 & 29.7 \\
\hline & Geo-Mean & 8.0 & 8.1 \\
\hline
\end{tabular}

\section{Relationship to lineaments}

According to Sami et al. (2002) regional-scale lineaments (related to faulting) are the most favourable drilling targets in the Limpopo Mobile Belt whereas small-scale faults have a poorer potential for groundwater. As a result, these (high-resolution) lineaments when mapped may well represent regionalscale faulting and lithological or tectonic contacts that may have higher water-bearing potential. The most significant correlation between transmissivity and proximity to lineaments is found in the Limpopo Plateau where the average and (geometric) mean transmissivity within $150 \mathrm{~m}$ of a lineament exceeds the average transmissivity values further away (Table 7). Based on the results, it can be generally accepted that lineaments have a positive influence on borehole productivity in the Eastern and Northern Bushveld Complex, Lowveld and Soutpansberg groundwater regions, whilst the influence of lineaments on borehole productivity in the Eastern Bankeveld and Waterberg regions is unconvincing.

Productive boreholes with high transmissivity values are not associated with only one lineament trend direction (Fig. 7), but the least favourable lineament trend (apart from the Limpopo Plateau) appears to be $\mathrm{W}$ to $\mathrm{WNW}\left(270^{\circ}\right.$ to $\left.300^{\circ}\right)$ with below-average transmissivities observed (Table 8).

It is generally expected that boreholes influenced by lineaments striking NW-SE (presumed to be under dilation and shear stress caused by the NW-SE maximum horizontal stress direction) should have higher productivities than boreholes associated with lineaments striking perpendicular to that direction. Groundwater regions with the most productive boreholes (highest transmissivities) associated with lineaments parallel to or slightly oblique to the current NW maximum horizontal

\begin{tabular}{|c|c|c|c|c|c|c|c|c|}
\hline \multicolumn{9}{|c|}{$\begin{array}{c}\text { Table } 8 \\
\text { Transmissivity }\left(T, \mathrm{~m}^{2} / \mathrm{d}\right) \text { classed according to lineament orientation (azimuth) (highlighted: dark grey = highest) }\end{array}$} \\
\hline & $\begin{array}{l}\text { Azimuth } \\
\text { class }\end{array}$ & $\begin{array}{c}-90^{\circ} \text { to } \\
-60^{\circ}\left(270^{\circ}\right. \\
\left.\text { to } 300^{\circ}\right)\end{array}$ & $\begin{array}{l}-60^{\circ} \text { to } \\
-30^{\circ}\left(300^{\circ}\right. \\
\left.\text { to } 330^{\circ}\right)\end{array}$ & $\begin{array}{c}-30^{\circ} \text { to } 0^{\circ} \\
\left(300^{\circ} \text { to }\right. \\
\left.360^{\circ}\right)\end{array}$ & $0^{\circ}$ to $30^{\circ}$ & $30^{\circ}$ to $60^{\circ}$ & $60^{\circ}$ to $90^{\circ}$ & Main trend \\
\hline \multirow{3}{*}{$\begin{array}{l}\text { Eastern } \\
\text { Bankeveld }\end{array}$} & $N$ & 5 & 5 & 6 & 8 & 5 & 10 & \multirow{3}{*}{$10^{\circ}$ to $45^{\circ}$} \\
\hline & Mean & 48.1 & 213.8 & 45.0 & 11.6 & 6.0 & 409.9 & \\
\hline & Geo- Mean & 13.0 & 6.0 & 13.3 & 5.3 & 3.8 & 19.1 & \\
\hline \multirow{3}{*}{$\begin{array}{l}\text { Eastern Bushveld } \\
\text { Complex }\end{array}$} & $N$ & 29 & 18 & 26 & 30 & 29 & 49 & \multirow{3}{*}{$\begin{array}{l}20^{\circ} \text { to } 80^{\circ}, \\
270^{\circ} \text { to } 300^{\circ}, \\
330^{\circ} \text { to } 345^{\circ}\end{array}$} \\
\hline & Mean & 50.2 & 36.3 & 24.4 & 51.2 & 80.1 & 24.2 & \\
\hline & Geo-Mean & 9.0 & 13.8 & 7.2 & 12.4 & 12.8 & 6.8 & \\
\hline \multirow{3}{*}{ Lowveld } & $N$ & 34 & 19 & 14 & 18 & 64 & 102 & \multirow{3}{*}{$40^{\circ}$ to $70^{\circ}$} \\
\hline & Mean & 16.3 & 19.3 & 198.0 & 52.7 & 20.6 & 19.0 & \\
\hline & Geo-Mean & 7.2 & 10.4 & 15.9 & 18.0 & 5.8 & 8.0 & \\
\hline \multirow{3}{*}{$\begin{array}{l}\text { Northern } \\
\text { Bushveld } \\
\text { Complex }\end{array}$} & $N$ & 4 & 4 & 1 & 6 & 12 & 11 & \multirow{3}{*}{$30^{\circ}$ to $80^{\circ}$} \\
\hline & Mean & 34.6 & 15.8 & - & 106.2 & 23.2 & 47.4 & \\
\hline & Geo-Mean & 14.3 & 6.1 & - & 23.4 & 12.6 & 28.5 & \\
\hline \multirow{3}{*}{ Limpopo Plateau } & $N$ & 25 & 17 & 12 & 6 & 22 & 37 & \multirow{3}{*}{$\begin{array}{c}40^{\circ} \text { to } 8^{\circ} \\
270^{\circ} \text { to } 290^{\circ}\end{array}$} \\
\hline & Mean & 56.5 & 50.2 & 39.8 & 66.5 & 47.6 & 47.5 & \\
\hline & Geo-Mean & 28.9 & 13.7 & 18.1 & 27.3 & 18.2 & 19.4 & \\
\hline \multirow{3}{*}{ Soutpansberg } & $N$ & 10 & 18 & 11 & 4 & 9 & 29 & \multirow{3}{*}{$\begin{array}{c}60^{\circ} \text { to } 90^{\circ}, \\
270^{\circ} \text { to } 330^{\circ}\end{array}$} \\
\hline & \begin{tabular}{|l|} 
Mean \\
\end{tabular} & 8.0 & 13.5 & 62.5 & 18.1 & 20.6 & 11.6 & \\
\hline & Geo-Mean & 3.7 & 6.6 & 13.7 & 7.6 & 13.3 & 5.1 & \\
\hline \multirow{3}{*}{$\begin{array}{l}\text { Waterberg } \\
\text { Plateau }\end{array}$} & $N$ & 13 & 2 & 3 & 2 & 5 & 24 & \multirow{3}{*}{$\begin{array}{c}70^{\circ} \text { to } 90^{\circ}, \\
270^{\circ} \text { to } 290^{\circ}\end{array}$} \\
\hline & Mean & 7.3 & 5.9 & 4.4 & 20.5 & 5.5 & 41.5 & \\
\hline & Geo-Mean & 1.6 & 3.3 & 2.1 & 6.3 & 4.4 & 4.6 & \\
\hline \multirow{3}{*}{ Total } & $N$ & 120 & 83 & 73 & 74 & 146 & 262 & \multirow{3}{*}{-} \\
\hline & Mean & 33.1 & 39.3 & 67.4 & 50.3 & 35.7 & 41.4 & \\
\hline & Geo-Mean & 8.6 & 9.8 & 11.1 & 13.3 & 8.8 & 8.7 & \\
\hline
\end{tabular}




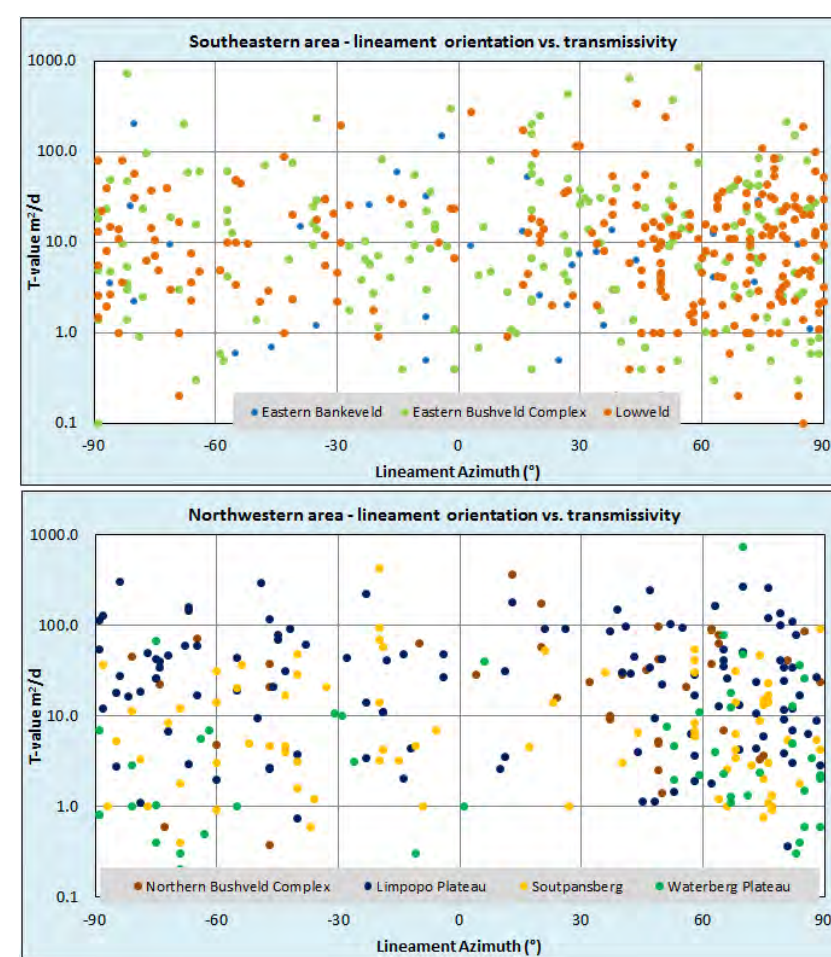

Figure 7

Plot of transmissivity in relation to the lineament azimuth (class) in the study area (grouped into the north-western and south-eastern parts)

Table 9

Influence of proximity to rivers on transmissivity $\left(\mathrm{m}^{2} / \mathrm{d}\right)$ (highlighted: dark grey $=$ highest)

\begin{tabular}{|c|c|c|c|}
\hline & Distance to river & $150 \mathrm{~m}$ & $>150 \mathrm{~m}$ \\
\hline \multirow{3}{*}{ Eastern Bankeveld } & $N$ & 40 & 210 \\
\hline & Mean & 117.6 & 50.0 \\
\hline & Geo-Mean & 16.0 & 9.8 \\
\hline \multirow{3}{*}{$\begin{array}{l}\text { Eastern Bushveld } \\
\text { Complex }\end{array}$} & $N$ & 60 & 585 \\
\hline & \begin{tabular}{|l|} 
Mean \\
\end{tabular} & 31.5 & 24.5 \\
\hline & Geo-Mean & 10.4 & 4.5 \\
\hline \multirow{3}{*}{ Lowveld } & $N$ & 133 & 1577 \\
\hline & Mean & 37.8 & 23.2 \\
\hline & Geo-Mean & 12.8 & 7.0 \\
\hline \multirow{3}{*}{$\begin{array}{l}\text { Northern Bushveld } \\
\text { Complex }\end{array}$} & $N$ & 19 & 157 \\
\hline & Mean & 54.1 & 53.9 \\
\hline & Geo-Mean & 23.2 & 21.3 \\
\hline \multirow{3}{*}{ Limpopo Plateau } & $N$ & 80 & 647 \\
\hline & Mean & 47.0 & 43.7 \\
\hline & Geo-Mean & 21.0 & 13.2 \\
\hline \multirow{3}{*}{ Soutpansberg } & $N$ & 28 & 385 \\
\hline & Mean & 14.2 & 17.7 \\
\hline & Geo-Mean & 6.6 & 6.0 \\
\hline \multirow{3}{*}{ Waterberg Plateau } & $N$ & 33 & 230 \\
\hline & Mean & 94.7 & 27.7 \\
\hline & Geo-Mean & 16.9 & 5.9 \\
\hline \multirow{3}{*}{ Total } & $N$ & 393 & 3791 \\
\hline & Mean & 50.7 & 29.3 \\
\hline & Geo-Mean & 14.1 & 7.6 \\
\hline
\end{tabular}

stress regime include the Eastern Bushveld Complex and the Limpopo Plateau and may have opened due this acting stress regime. However, based on the results it seems that higher borehole productivities are in fact associated with lineaments perpendicular to the current stress regime, more specifically ENE to E. This was also noted by the case studies on the Limpopo Mobile Belt by Sami et al. (2002), where lineaments orientated ENE-WSW were regarded as the most favourable hydrogeological feature. Groundwater regions associated with this trend include the Eastern Bankeveld, Northern Bushveld Complex and Waterberg. In the Lowveld region boreholes associated with lineaments striking WNW to $\mathrm{NNE}\left(330^{\circ}\right.$ to $\left.30^{\circ}\right)$ offer superior productivities compared to boreholes associated with the common NE to ENE lineament trend observed for this area (Table 8). This is also true for the entire dataset where the highest (geometric) means are observed for this WNW to NNE $\left(330^{\circ}\right.$ to $\left.30^{\circ}\right)$ trend

\section{Proximity to rivers}

To determine the influence of drainage channels on borehole productivity, a spatial assessment of proximity was conducted. Boreholes within $150 \mathrm{~m}$ of major surface drainages have above-average transmissivity (2 to 3 times higher) compared to boreholes further away, indicating the strong influence of surface-water bodies on borehole productivity. In most cases these highly productive areas are associated with elongated primary alluvial aquifers. In addition, drainage channels tend to follow zones of structural weaknesses (e.g. lineaments) in the near surface; therefore rocks in the vicinity of rivers might be more intensely fractured, jointed and/or weathered.

\section{Conclusion}

The hard fractured rocks of the study area can be characterised by a generally thin regolith where groundwater aquifers are primarily structurally controlled. Historical groundwater exploration within the area has successfully targeted structural features and geological contacts at depth within the unweathered bedrock instead of in the rather thin regolith. The influence of specific factors was determined by dividing the large borehole dataset available into various categories using transmissivity as a measure of borehole productivity. While the geological analysis of the data set indicates the obvious, that the rock type and lithology influence borehole productivity, the 7 groundwater regions identified within the study area show distinct differences in groundwater potential suggesting that the factors involved in controlling borehole productivity vary with each setting. Geology has been identified as the main influence on borehole productivity while proximity to surfacewater drainages has an obvious influence on the groundwater potential. The analysis on the influence of dykes and lineaments on borehole productivity is based on specific assumptions and limitations. These are mainly inherited from the accuracy of the mapping of these structures and the potential zone of influence. The scale of the assessment also neglects the influence of local-scale features but at the same time provides a large dataset from which statistically meaningful results can be obtained. Although boreholes that intercepted dykes have higher transmissivities compared to boreholes that did not intercept dykes, there is no relationship between the borehole productivity and proximity to the dyke. Dykes are an important water-bearing feature in the Limpopo Plateau compared to the Letaba Lowveld which suggests that the permeability of 
the host rock plays an important part in whether the dyke will act as a conduit that transports groundwater or as a barrier to groundwater flow. In addition, dykes composed of dolerite may prove to be more successful than dykes composed of diabase. The proximity of lineaments plays a role on borehole productivity and based on the transmissivity results it is assumed that the intensity of fracturing decreases with increasing distance away from the lineament. Although highly variable, a number of specific lineament orientations provide above-average transmissivities. Generally (apart from the Limpopo Plateau and the Eastern Bushveld Complex), boreholes associated with lineaments striking perpendicular to the current (NW-SE) maximum horizontal stress direction suggest higher productivities. The regional dataset for the Limpopo Province suggests more favourable groundwater conditions targeting lineaments striking $\mathrm{N}$ to NNE. These lineaments would have formed under extensional stresses providing suitable groundwater targets. However, due to the complex geological history of the area, it is difficult to link open discontinuities to a distinct recent or past tectonic event. It can be concluded that regional stress-field data, as in this case, may not account for local, possibly highly significant, stress-field variations. To increase the confidence in the somehow limited relationship between borehole productivity and lineament (including dyke) orientation, further detailed analysis with focus on lineament interpretation, classification and field verification, in addition to regional geological surveys, is necessary. The hydrogeological importance of several factors on groundwater occurrence presented in this study can be used as a working reference for future groundwater development programmes.

\section{Acknowledgments}

The author would like to thank the South African Department of Water Affairs, of the Limpopo Regional Office, for providing the borehole and lineament dataset. Comments on the manuscript from the reviewers and editors are greatly appreciated.

\section{References}

ANKE F (2008) ASTER Satellite Image Lineament Interpretation, 1: 50000 Scale. Groundwater Resource Information Project. Department of Water Affairs, Polokwane.

BANKS D and ROBINS N (2002) An Introduction to Groundwater in Crystalline Bedrock. Geological Survey of Norway, Trondheim.

BIRD P, BEN-AVRAHAM Z, SCHUBERT G, ANDREOLI M and VIOLA G (2006) Patterns of stress and strain rate in southern Africa. K. Geophys. Res. 111 (B8) B08402. DOI: 10.1029/2005JB003882.

BOSHOFF R, VAN REENEN DD, SMIT CA, PERCHUK LL, KRAMERS JD and ARMSTRONG, R (2006) Geologic history of the central zone of the Limpopo Complex: The West Alldays Area. J. Geol. 114 699-716.

BRAATHEN A and GABRIELSEN R (1998) Lineament Architecture and Fracture Distribution in Metamorphic and Sedimentary Rocks, with Application to Norway. Geological Survey of Norway Report No. 98.043. Geological Survey of Norway, Trondheim.

BRANDL G, CLOETE M and ANHAEUSSER CR (2006) Archaean Greenstone Belts. In: Johnson MR, Anhaeusser CR and Thomas RJ (eds.) The Geology of South Africa. Geological Society of South Africa, Johannesburg/Council for Geoscience, Pretoria, South Africa. 209-236.

BROMLEY J, MANSTROM B, NISCA D and JAMTLID AA (1994) Airborne geophysics: application to ground-water study in Botswana. Ground Water 32 79-90.

BUSH RA (1989) A Geohydrological Assessment of the Swartwater and Beauty Areas, Northern Western Transvaal. Report No. GH
3577. Directorate of Geohydrology, Department of Water Affairs and Forestry, Pretoria, South Africa.

CHILTON PJ and FOSTER SSD (1995) Hydrological characterization and water-supply potential of crystalline aquifers in tropical Africa. Hydrogeol. J. 3 36-49.

CLARK L (1985) Groundwater abstraction from Crystalline Complex areas of Africa. Q. J. Eng. Geol. 18 25-34.

COOPER HH and JACOB CE (1946) A generalized graphical method for evaluating formation constants and summarizing well field history. Am. Geophys. Union Trans. 27 526-534.

DE MARSILY G, DELAY F, GONÇALVÈS J, RENARD PH, TELES $\mathrm{V}$ and VIOLETTE S (2005) Dealing with spatial heterogeneity. Hydrogeol. J. 15 161-183.

DU TOIT WH (2001) The influence of granite intrusions on the host rock in terms of occurrence in groundwater in the Pietersburg area. M.Tech. (Geology) Thesis. Technicon Pretoria, South Africa.

FERNANDES AJ and RUDOLPH DL (2001) The influence of Cenozoic tectonics on the groundwater production capacity of fractured zones: a case study in São Paulo, Brazil. Hydrogeol. J. 9 151-167.

GREENBAUM D (1992) Structural influence on the occurrence of groundwater in SE Zimbabwe. In: Wright EP and Burgess WG (eds.) The Hydrogeology of Crystalline Basement Aquifers in Africa. Geological Society Special Publication No. 66. Geological Society, London. 77-87.

GUSTAFSON G and KRÁSNÝ, J (1994) Crystalline rock aquifers: Their occurrence, use and importance. Appl. Hydrogeol. 2 64-75.

HEIDBACH O, TINGAY M, BARTH A, REINECKER J, KURFESS D and MÜLLER B (2008) The World Stress Map Database Release 2008. DOI: 10.1594/GFZ.WSM.Rel2008.

HENRIKSEN H and BRAATHEN A (2003) Effects of fracture lineaments and in-situ rock stresses on groundwater flow in hard rocks: a case study from Sunnfjord, western Norway. Hydrogeol. J. 14 444-461.

HENRIKSEN H (1995) Relation between topography and well yield in boreholes in crystalline rocks, Sogn og Fjordane, Norway. Ground Water 33 635-643.

HOEKSEMA RJ and KITANIDIS PK (1985) Analysis of the spatial structure of properties of selected aquifers. Water Resour. Res. 21 (4) 563-572.

HOLLAND M and WITTHÜSER KT (2011) Evaluation of geologic and geomorphologic influences on borehole productivity in crystalline bedrock aquifers of Limpopo Province, South Africa. Hydrogeol. J. 19 1065-1083.

KRÂSNY, J (1997) Transmissivity and permeability distribution in hard rock environment: a regional approach. Proc. Symposium on Hard Rock Hydrosystems. S2 at Rabat, IAHS Publication No. 241, 81-90.

LOGAN J (1964) Estimating transmissivity from routine production tests of water wells. Ground Water 2 35-37.

MABEE SB, HARDCASTLE KC and WISE DW (1994) A method of collecting and analyzing lineaments for regional-scale fractured bedrock aquifer studies. Ground Water 32 (6) 884-894.

MABEE SB (1999) Factors influencing well productivities in glaciated metamorphic rocks. Ground Water 37 88-97.

McFARLANE MJ, CHILTON PJ and LEWIS MA (1992) Geomorphological controls on borehole yields: a statistical study in an area of crystalline rocks in central Malawi. In: Wright EP and Burgess WG (eds.) The Hydrogeology of Crystalline Basement Aquifers in Africa. Geological Society Special Publication No 66. Geological Society, London. 131-155.

NEVES MA and MORALES N (2007) Well productivity controlling factors in crystalline terrains of southeastern Brazil. Hydrogeol. J. 15 471-482.

OWEN R, MAZITI A and DAHLIN T (2007) The relationship between regional stress field, fracture orientation and depth of weathering and implications for groundwater prospecting in crystalline rocks. Hydrogeol. J. 15 1231-1238.

PINALES A, CHAVEZ A, LLERAR G, MANZANARES L and KEER K (2005) An improved approach for assigning pumping rates to heterogeneous aquifer models. Ground Water 43 (2) 274-279. 
RANGANAI RT and EBINGER CJ (2008) Aeromagnetic and Landsat TM structural interpretation for identifying regional groundwater exploration targets, south-central Zimbabwe Craton. J. Appl. Geophys. 65 73-83.

RAZACK M and LASM T (2006) Geostatistical estimation of the transmissivity in a highly fractured metamorphic and crystalline aquifer (Man-Danane Region, Western Ivory Coast). J. Hydrol. 325 164-178.

SAMI K, NEUMAN I, GQIBA D, DE KOCK G and GRANTHAM G (2002) Groundwater Exploration in Geologically Complex and Problematic Terrain. WRC Report No. 966/2/02. Water Research Commission, Pretoria, South Africa.

SANDER P (2007) Lineaments in groundwater exploration: a review of applications and limitations. Hydrogeol. J. 15 71-74.

SOLOMON S and QUIEL F (2006) Groundwater study using remote sensing and geographic information systems (GIS) in the central highlands of Eritrea. Hydrogeol. J. 14 729-741.

STETTLER EH, DE BEER JH and BLOM MP (1989) Crustal domains in the northern Kaapvaal as defined by magnetic lineaments. Precambrian Res. 45 263-276.
THEIS CV (1935) The relation between the lowering of the piezometric surface and the rate and duration of discharge of a well using ground-water storage. Am. Geophys. Union Trans. 14 519-524.

UKEN R and WATKEYS MK (1997) An interpretation of mafic dyke swarms and their relationship with major mafic magmatic events on the Kaapvaal Craton and Limpopo Belt. S. Afr. J. Geol. 100 (4) 341-348.

VAN TONDER GJ, BOTHA JF, CHIANG WH, KUNSTMANN H and XU Y (2001) Estimation of the sustainable yields of boreholes in fractured rock formations. J. Hydrol. 241 70-90.

VEGTER JR (2000) Groundwater Development in South Africa and an Introduction to the Hydrogeology of Groundwater Regions. WRC Report No. TT 134/00. Water Research Commission, Pretoria, South Africa.

WISE DU (1982) Linesmanship and the practice of linear geo-art. Geol. Soc. Am. Bull. 93 886-888.

WRIGHT EP (1992) The hydrogeology of crystalline basement aquifers in Africa. In: Wright EP and Burgess WG (eds.) The Hydrogeology of Crystalline Basement Aquifers in Africa. Geological Society Special Publication No. 66. Geological Society, London. 